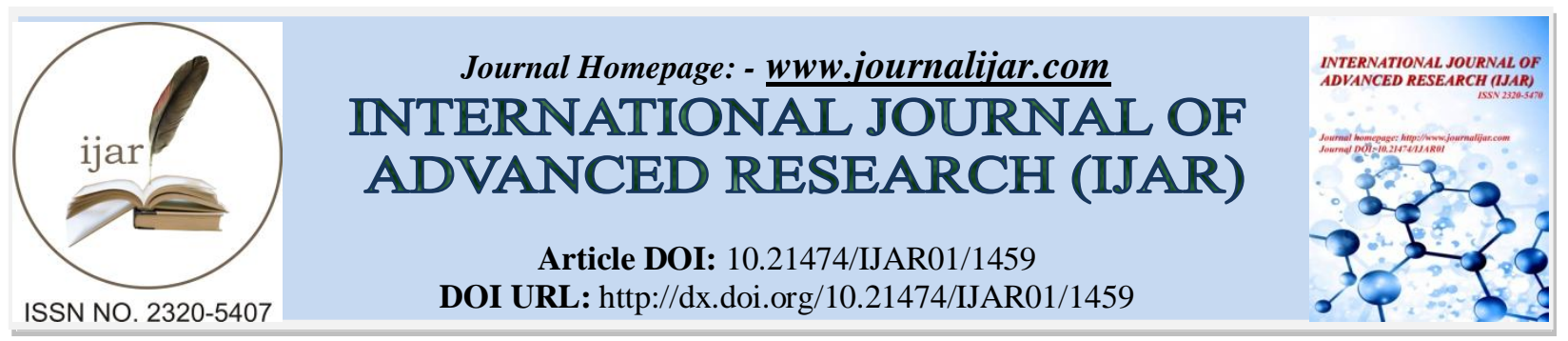

RESEARCH ARTICLE

\title{
ADSORPTION OF SILVER (I) FROM AQUEOUS SOLUTIONS ONTO ACTIVATED CARBON PREPARED FROM ALGERIAN DATES STONES OF PHOENIX DACTYLIFERA.L (GHARS VARIETY) BY $\mathrm{H}_{3} \mathrm{PO}_{4}$ ACTIVATION.
}

\author{
Noura. Chaouch ${ }^{1} *$ and Mouhammed Ridha. Ouahrani ${ }^{2}$ \\ 1. Faculty of Applied Sciences, Ouargla University, Ouargla, Algeria. \\ 2. Valorization and Technology of Saharian Resource Laboratory, Faculty of Science and Technology, El Oued \\ University, El Oued, Algeria.
}

\section{Manuscript Info}

Manuscript History

Received: 14 July 2016

Final Accepted: 16 August 2016

Published: September 2016

Key words:-

Adsorption, Activated carbon, Silver removal, Thermodynamic, Langmuir model, Freundlich model.

\section{Abstract}

The removal of toxic heavy metals from aqueous environment has received considerable attention in recent years due to their toxicity which may cause damage to various systems of the human body. Currently activated carbon is a common adsorbent used to remove heavy metals contaminants. The main object of this study was the use of an activated carbon prepared from nuts of dates Algerian origin to remove silver from aqueous solutions. The adsorption measurement of silver on activated carbon showed a real potential for removing this metal contaminants waste. The result showed also that the determination of silver remained dependent on some parameters such as $\mathrm{pH}$, time contact, temperature and initial concentration of metal. Adsorption data followed Freundlich isotherm, they were better fitted by Langmuir isotherm.

Copy Right, IJAR, 2016,. All rights reserved.

\section{Introduction:-}

For humans, heavy metals can cause the degeneration of living cells and to tackle the various organs, they play the role of endocrine disruptors with excellence. Their accumulation in the body can disrupt its internal organization and cause pathologies affecting their physical, mental and even genetic integrity. They also can be absorbed by marine animals and directly enter the human food chains, thus presenting a high health risk to consumers [1 - 4]. It is therefore understandable that every vital function of man is endangered by the presence of toxic heavy metals in the environment.

Silver is toxic in high doses. Argyria, generally therapeutic origin can expand to daily doses of $0.5 \mathrm{mg}$. It results in digestive disorders, gingival and stroked a whitish gray discoloration of the skin by forming colloidal silver chloride starting from a concentration of $0.015 \mathrm{mg} / \mathrm{l}$. This discoloration is dominant on the face, discoveries and on angles regions. The doses without adverse effects observed for argyria corresponds to $10 \mathrm{~g}$ of silver at all throughout life. With regard to aquatic life, concentrations as low as $10 \mathrm{mg} / \mathrm{l}$ may cause toxic effects in freshwater fish.

Several methods are commonly used for the treatment of heavy metals, such as adsorption, chemical precipitation, coagulation, flocculation, extraction and reverse osmosis [5 - 9]. Most of these process need high capital cost [10]. They have great disadvantage by operating in a succession of steps of heterogeneous reactions, or distribution of

Corresponding Author:- Noura. Chaouch.

Address:- Faculty of Applied Sciences, Ouargla University, Ouargla, Algeria. 
substances between different phases, which usually requires a lengthy operating period. Moreover, the final metal recovery requires additional treatments, which complicate the process.

Adsorption has been shown to be an economical alternative for removing trace of metals from water. Among the numerous materials applied in adsorption processes, activated carbons, primarily due to their low cost and high adsorption ability, are still the most widely used materials for adsorption of impurities [11].

Basically, there are two different processes for the preparation of activated carbon: physical activation and chemical activation. In chemical activation, the precursor is mixed with a chemical agent and then pyrolyzed between 673 and $873 \mathrm{~K}$ in the absence of air [4].

Among the numerous dehydrating agents, phosphoric acid in particular is the widely used chemical agent in the preparation of activated carbons $[\mathbf{1 1}, \mathbf{1 2}]$.

The aim of this work was to evaluate the feasibility of using activated carbon prepared from an Algerian dates stones of Phoenix dactylifera.L (Ghars variety) cultivated in Ouargla region situated in the south of Algeria for the removal of $\mathrm{Ag}$ (I) from aqueous solution. The influence of experimental conditions such as $\mathrm{pH}$, contact time, initial metal concentration and solution temperature were studies.

\section{Materials and methods:-}

The tests stock solutions were prepared by dissolving silver nitrate $\mathrm{AgNO}_{3}$ in distilled water. The $\mathrm{pH}$ of the test solutions was adjusted using hydrochloric acid $(0.1 \mathrm{M})$ or sodium hydroxide $(0.1 \mathrm{M})$ [5].

\section{Materials:-}

The $\mathrm{pH}$ measurements were made using a pH meter (Hanna 4221).The silver concentrations in the sample were determined using atomic adsorption spectrophotometer (Thermoelectron corporation). During adsorption tests, a shaker (flask) was used. A furnace (Select-Horn) was utilized in the preparation of activated carbon. The other equipments used in the characterization of adsorbent are being listed in the next section.

\section{Preparation and characterization of adsorbent:-}

The starting material for the preparation of activated carbon was the dates stones of Phoenix dactylifera. L (Ghars variety) (Ouargla, Algeria), a waste agricultural product. Phosphoric acid was used for chemical activation. A ratio of $(1: 1.5)(\mathrm{w} / \mathrm{w})$ powdered raw material and acid was prepared before distilled water was added in order to remove the impurities. Then, After 2 hours, the precursor was dried at $105^{\circ} \mathrm{C}$ and heated to $450^{\circ} \mathrm{C}$. It was washed with distilled water, dried, and sieved to desired particle size $[\mathbf{5}, \mathbf{1 3}, \mathbf{1 4}]$.

The surface area and pore size of the adsorbent were measured by means of a nova surface area analyzer using a Brunauer-Emmett-Teller (BET) nitrogen adsorption technique. The average pore size and total pore volume were also determined in the same way. Table 1 displays the characteristics of adsorbent.

Table 1:- Characteristics of activated carbon.

\begin{tabular}{|l|l|}
\hline Physical properties & Activated carbon \\
\hline BET surface area $\left(\mathrm{m}^{2} / \mathrm{g}\right)$ & $\mathbf{5 4 . 9 3}$ \\
\hline Average pore radius $(\mathrm{nm})$ & 1.13 \\
\hline Total pore volume $\left(\mathrm{cm}^{3} / \mathrm{g}\right)$ & $1.5510^{-2}$ \\
\hline Porosity $(\%)$ & $\mathbf{7 0}$ \\
\hline True density $\left(\mathrm{g} / \mathrm{cm}^{3}\right)$ & 0,45 \\
\hline Particle density $\left(\mathrm{g} / \mathrm{cm}^{3}\right)$ & $\mathbf{0 , 5 1}$ \\
\hline
\end{tabular}

\section{Adsorption experiments:-}

The stock monovalent cation solution $\left(\mathrm{Ag}^{+}\right)$was prepared by dissolving silver nitrate in bi-distilled water at $1000 \mathrm{mg} / \mathrm{l}$. Working solutions were prepared by diluting different volumes of stock solution to achieve the desired concentration. 
In the batch studies, $0.1 \mathrm{~g}$ of the adsorbent was placed in a flask containing $20 \mathrm{ml}$ of a silver solution with the desired concentration. The flask was continuously shaken $(50 \mathrm{rpm})$ at a desired temperature and $\mathrm{pH}$ range $(2-10)$. At the end of each step, the supernatant liquids were filtered and the $\operatorname{Ag}(\mathrm{I})$ concentrations were determined using an atomic adsorption spectrophotometer. The contact time was determined as the time required for the concentration of the silver in the solution to reach equilibrium (1h). The amount of metal adsorbed by the solid (q) and the percent of metal removal were calculated using the following equations:

$$
\begin{gathered}
\mathbf{q}=\left(\mathrm{C}_{0}-\mathrm{C}_{\mathrm{e}}\right) \mathrm{V} / \mathrm{m} \\
\text { Metal ions removal }(\%)=\left(\mathrm{C}_{0}-\mathrm{C}_{\mathrm{e}}\right) 100 / \mathrm{C}_{0}
\end{gathered}
$$

Where $\mathbf{C}_{\mathbf{0}}$ is the initial concentration of $\mathrm{Ag}(\mathrm{I})(\mathrm{mg} / \mathrm{l}), \mathbf{C}_{\mathrm{e}}$ is the concentration of $\mathrm{Ag}(\mathrm{I})$ at equilibrium adsorption $(\mathrm{mg} / \mathrm{l}), \mathbf{V}$ is the volume of solution (l) and $\mathbf{m}$ is the mass of adsorbent $(\mathrm{g})$.

The effect of temperature ranging from 25 to $60^{\circ} \mathrm{C}$ was also studied. During the tests, the $\mathrm{pH}$ was adjusted to 2 and the contact time was set at $1 \mathrm{~h}$. The effect of $\mathrm{pH}(2-10)$ and the initial concentration of metal $(5-50 \mathrm{mg} / \mathrm{l})$ was also examined in order to determine its influence on the adsorption rate and also to obtain the adsorption isotherm. The shaking speed $(50 \mathrm{rpm})$, the amount of adsorbent $(0.1 \mathrm{~g})$, the contact time $(1 \mathrm{~h})$, the $\mathrm{pH}=2$, and the temperature of $25^{\circ} \mathrm{C}$ were kept constant.

\section{Results and Discussion:- Effect of pH:-}

The removal of metal ions from aqueous solution by adsorption is highly dependent on the $\mathrm{pH}$ of the solution, which affects the surface charge on the adsorbent and the degree of ionization of metal [4].

To check the effect of $\mathrm{pH}$ on $\mathrm{Ag}(\mathrm{I})$ adsorption using activated carbon prepared from dates stones as adsorbent, experiments were conducted by varying $\mathrm{pH}$ from 2 to 10 with an initial concentration of $50 \mathrm{mg} / \mathrm{l}$. The results obtained for adsorbent are shown in Figure 1.

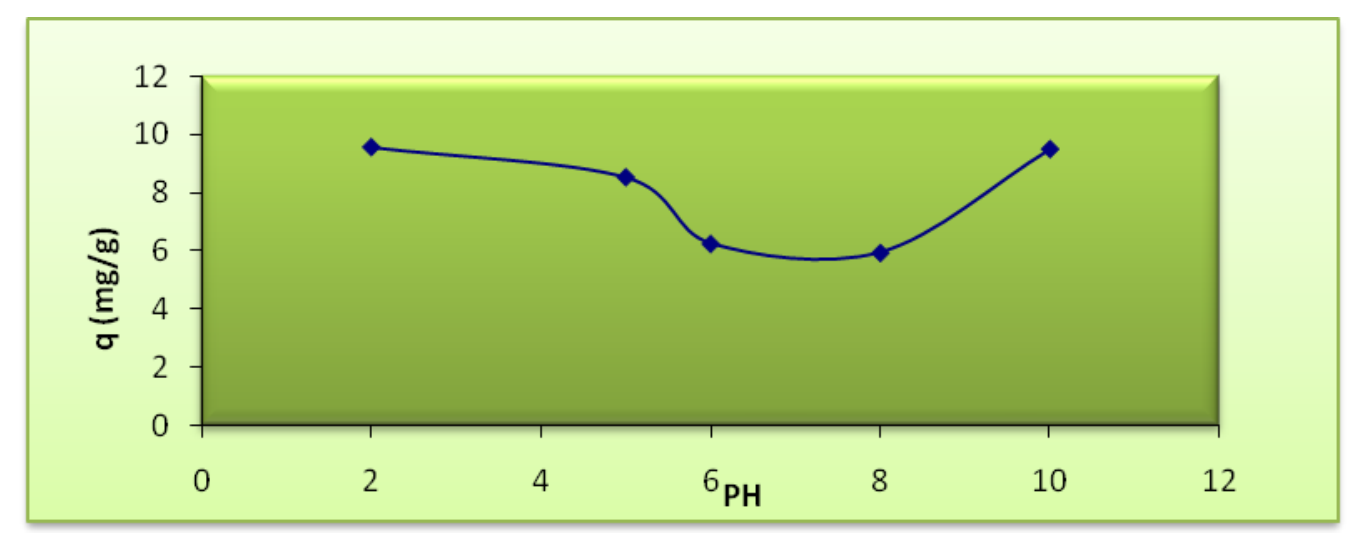

Fig. 1:- Effect of $\mathrm{pH}$ on the removal of $\mathrm{Ag}(\mathrm{I})$.

The best adsorption money rates are obtained at $\mathrm{pH}$ values of extreme or strongly acidic $(\mathrm{pH}=2)$ or highly basic $(\mathrm{pH}=10)$, they reach a maximum of $94.66 \%$ at $\mathrm{pH} 02$ or $9.45 \mathrm{mg} / \mathrm{g}$. Decreasing the adsorption of silver in the $\mathrm{pH}$ domain ranging from 05 to 06 is probably due to complex surface phenomena. So, we can note that the optimal $\mathrm{pH}=2$.

\section{Effect of contact time:-}

The effect of the contact time on the adsorption $\mathrm{Ag}$ (I) by activated carbon is shown in figure 2 . These data have been obtained from starting adsorbent and working solution without any $\mathrm{pH}$ adjustment $(\mathrm{pH}=2)$. The results showed that increasing the contact time increased the ions adsorption and then leveled up after $1 \mathrm{~h}$.

Consequently, the contact time was set to $1 \mathrm{~h}$ in each experiment. The amount of adsorbed silver by activated carbon from an initial concentration of $50 \mathrm{mg} / \mathrm{l}$ after $1 \mathrm{~h}$ was $9.80 \mathrm{mg} / \mathrm{g}$. 


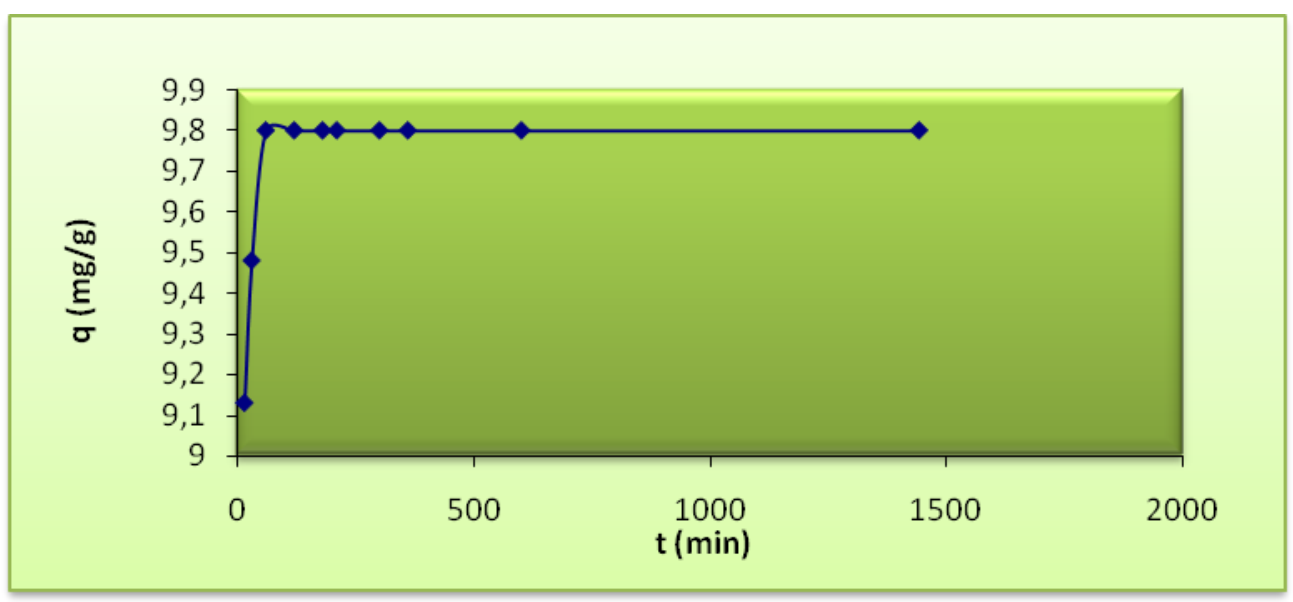

\section{Effect of temperature:-}

Fig. 2:- Effect of the contact time on the removal of $\mathrm{Ag}(\mathrm{I})$.

To investigate the effect of the temperature $\left(25,35,45\right.$ and $\left.60^{\circ} \mathrm{C}\right)$ on the $\operatorname{Ag}(\mathrm{I})$ adsorption, the experiments were conducted with constant concentration of $\mathrm{Ag}(\mathrm{I})(50 \mathrm{mg} / \mathrm{l}), \mathrm{pH}=2$, amount of activated carbon $(0.1 \mathrm{~g})$ and contact time (1h). The results are given in figure 3.

As can be seen from this figure, the adsorbed amount of $\mathrm{Ag}(\mathrm{I})$ ions decrease when increasing temperature from 25 to $60^{\circ} \mathrm{C}$.

The observed decrease in the adsorption capacity with an increase of temperature indicated that low temperature is in favor $\mathrm{Ag}(\mathrm{I})$ ions removal by adsorption onto activated carbon. This may be due to a tendency of the $\mathrm{Ag}(\mathrm{I})$ ions to escape from the solid phase to the bulk phase with an increase in the temperature of the solutions. This effect suggested that the adsorption mechanism associated with the removal of $\mathrm{Ag}(\mathrm{I})$ onto activated carbon involves a physical process, which is usually associated with low adsorption heat. This means that the adsorption process has an exothermic character.

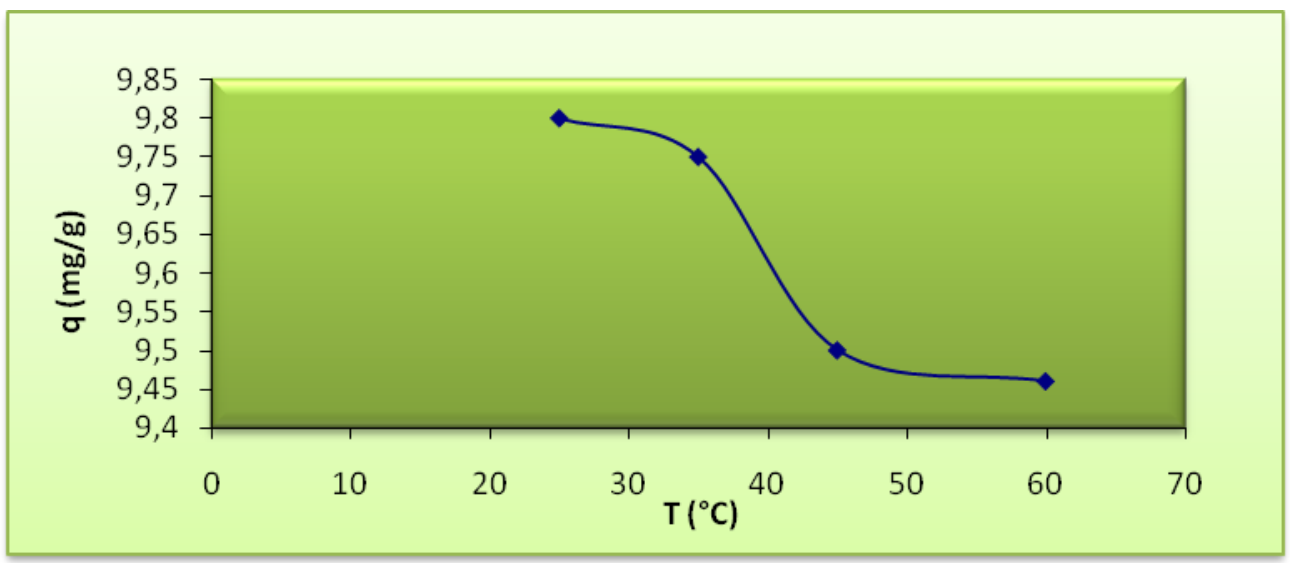

Fig. 3:- Effect of the temperature on the removal of $\mathrm{Ag}(\mathrm{I})$.

\section{Effect of initial concentration of metal:-}

Dependency of the process of $\mathrm{Ag}(\mathrm{I})$ removal from different initial concentrations $(5-50 \mathrm{mg} / \mathrm{l})$ by the activated charbon is illustrated in figure 4. The examination of the data reveals that the amount of absorbed silver increases with the concentration of solution from $0,92 \mathrm{mg} / \mathrm{g}$ to $9.80 \mathrm{mg} / \mathrm{g}$. The percentage of adsorption increases also from 92.40 to $97.98 \%$. 


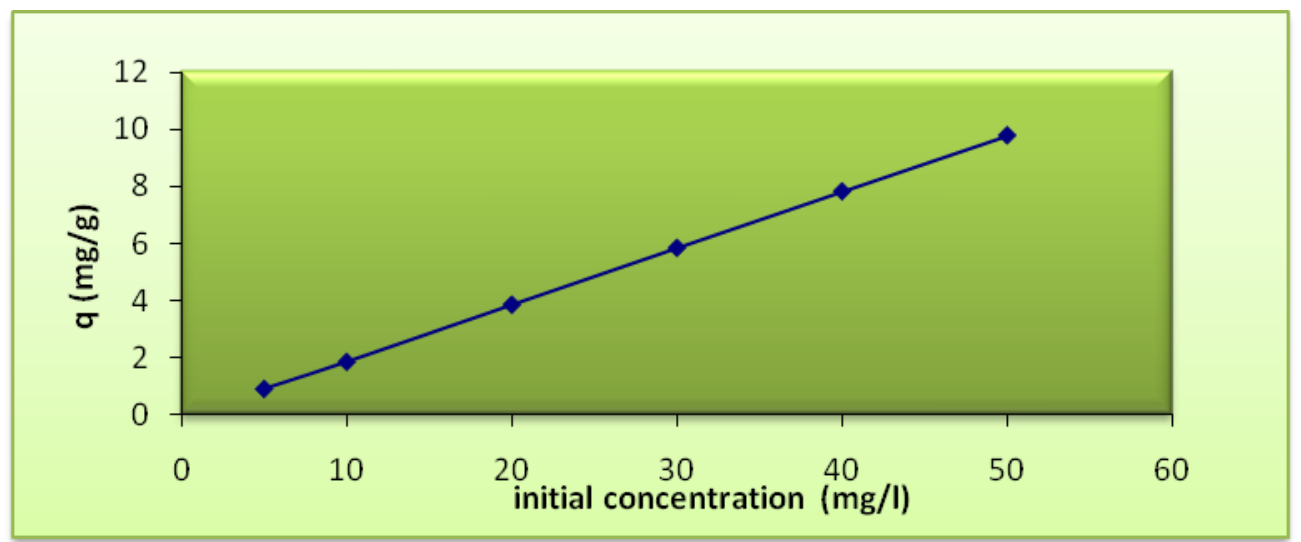

Fig. 4:- Effect of the initial concentration of meal on the adsorption of $\mathrm{Ag}(\mathrm{I})$ onto activated carbon.

\section{Adsorption isotherms:-}

The equilibrium adsorption isotherms are of fundamental importance in the study and design of adsorption systems. According to the slop of the initial portion of the curves, they are classified into various groups. In this work, the isotherm curve corresponds to S-type in Giles's classification (Figure 5).

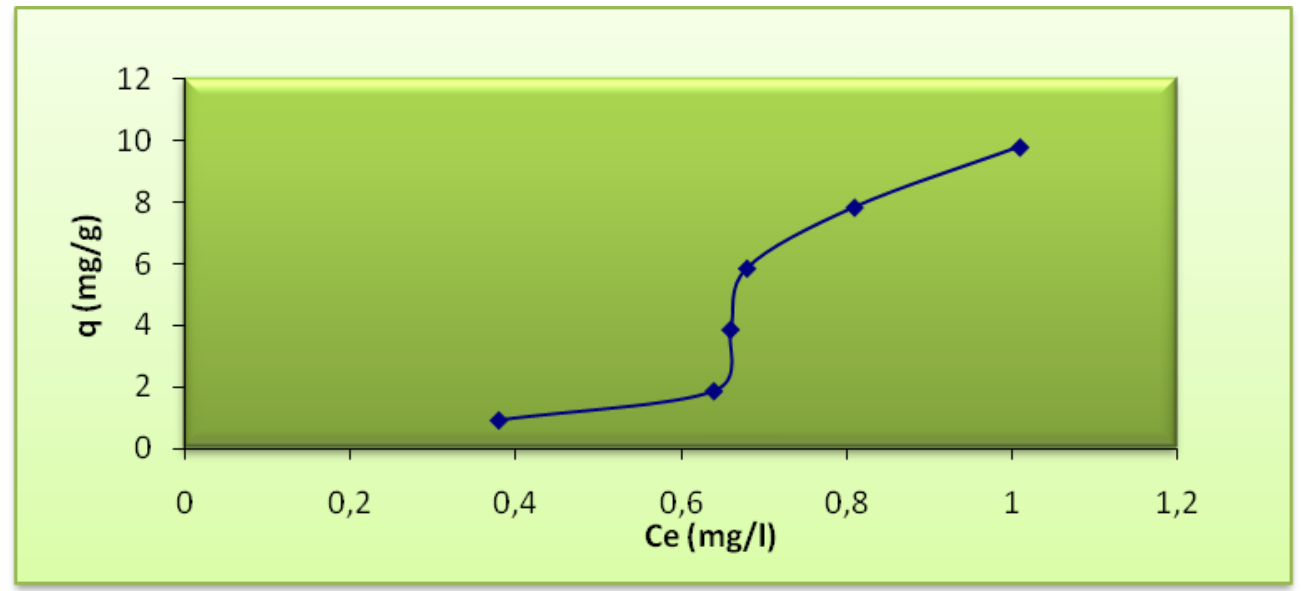

Fig. 5:- Adsorption isotherm of $\mathrm{Ag}(\mathrm{I})$ onto activated carbon.

Several methods have been published in the literature to describe experimental data of adsorption isotherms. The Langmuir and Freundlich models are the most frequently employed models. In this work, both models were used to describe the relationship between the amount of $\mathrm{Ag}(\mathrm{I})$ ions adsorbed and its equilibrium concentration in solution at $25, \mathrm{pH}=2$, for initial concentrations of 5, 10, 20,30, 40 and $50 \mathrm{mg} / \mathrm{l}$ during $1 \mathrm{~h}$.

The linear form of the Langmuir isotherm model can be represented by the using equation below:

$$
C_{e} / q=1 / q_{o} b+\left(1 / q_{o}\right) C_{e}
$$

Where $\mathbf{q}$ is the amount of solute adsorbed per unit weight of adsorbent $(\mathrm{mg} / \mathrm{g}), \mathbf{C}_{\mathbf{e}}$ is the equilibrium of concentration of solute in the bulk solution $(\mathrm{mg} / \mathrm{l}), \mathbf{q}_{\mathbf{o}}$ is the monolayer adsorption capacity $(\mathrm{mg} / \mathrm{g})$ and $\mathbf{b}$ is the constant related to the free energy of adsorption. The constants of Langmuir isotherm are obtained by plotting $\mathrm{C}_{\mathrm{e}} / \mathrm{q}_{\mathrm{e}}$ versus $\mathrm{C}_{\mathrm{e}}$ (figure 6). They are given in the table 2 .

The linear form of the Freundlich isotherm model is given by the following equation:

\section{$\log q=\log K+1 / n \log C_{e}$}

Where $\mathbf{K}$ is the constant indicative of the relative adsorption capacity of the adsorbent $(\mathrm{mg} / \mathrm{g})$ and $\mathbf{n}$ is the constant indicative of the intensity of the adsorption. The constants of Freundlich isotherm are obtained by plotting Log $\mathrm{q}$ versus $\log C_{e}$ (figure 7). They are given also in the table 2 


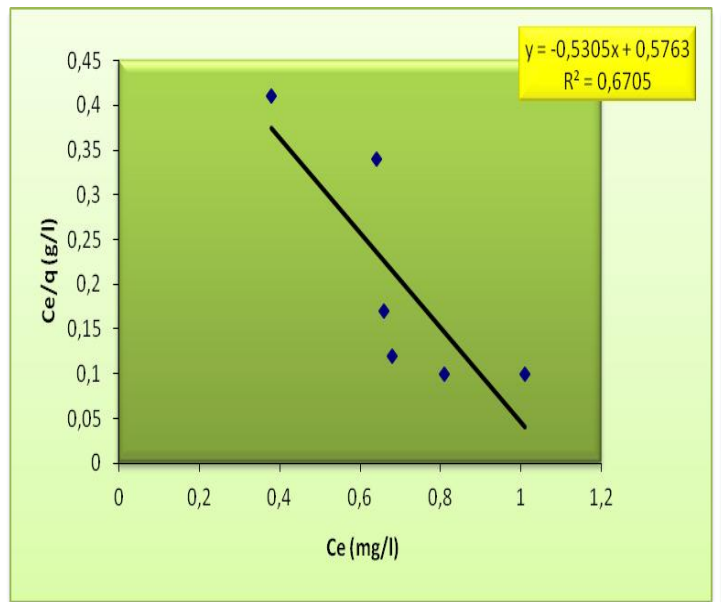

Fig. 6:- Langmuir isotherm.

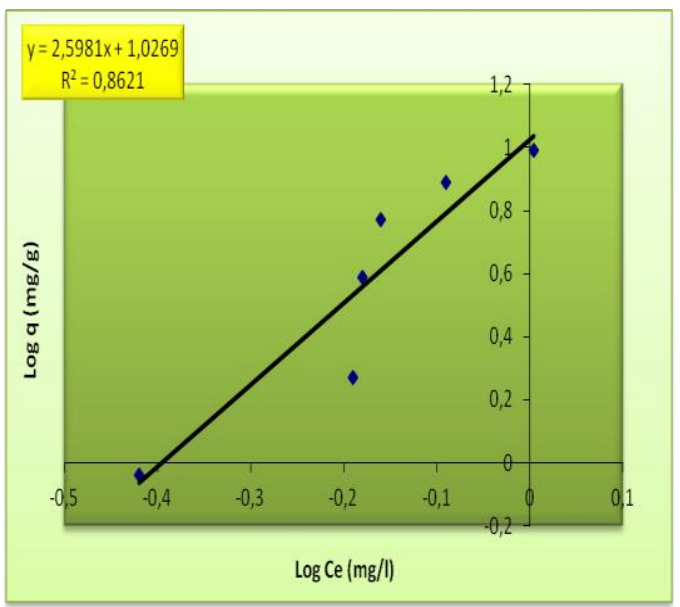

Fig. 7:- Freundlich isotherm.

Table 2:- Constants of Freundlich and Langmuir in the adsorption of $\mathrm{Ag}(\mathrm{I})$ onto activated carbon.

\begin{tabular}{|c|c|c|c|c|c|}
\hline \multicolumn{3}{|c|}{ Langmuir model } & \multicolumn{3}{c|}{ Freundlich model } \\
\hline $\mathrm{q}_{0}(\mathrm{mg} / \mathrm{g})$ & $\mathrm{b}(\mathrm{l} / \mathrm{mg})$ & $\mathbf{R}^{\mathbf{2}}$ & $\mathrm{K}\left(\mathrm{mg}^{1-\mathrm{n}} \mathrm{l}^{\mathrm{n}} \mathrm{g}^{-1}\right)$ & $\mathrm{n}$ & $\mathbf{R}^{\mathbf{2}}$ \\
\hline-1.8850 & -0.9205 & 0.5705 & 10.6389 & 2.5981 & 0.8621 \\
\hline
\end{tabular}

The value of $\mathrm{n}$ (2.5981) represent a small but a beneficial adsorption of $\mathrm{Ag}$ (I) onto activated carbon. The correlation coefficients indicate that the adsorption process conforms to the Freundlich model.

\section{Conclusion:-}

It can be concluded that activated carbons with high adsorption capacities can be produced from Algerian dates stones (Ghars variety) by chemical activation with phosphoric acid and can be employed as adsorbent for the removal of silver (I) from aqueous solutions. However, the $\mathrm{pH}$, time contact, temperature and initial concentration of metal could either affect the adsorption capacities of the activated carbon positively or negatively depending on the range of the parameters. The experimental data of adsorption of $\mathrm{Ag}(\mathrm{I})$ followed the Freundlich model.

The results of this study may be helpful to environmental sanitary engineers for designing and establishing a continuous treatment plant for both water and wastewaters.

\section{References:-}

1. Rozada, F., Otero, M., Moran, A. and Garcia, A.I. (2008): Adsorption of heavy metals onto sewage sludge derived materials. Bioresource technol., 99: 6332- 6338.

2. Ahmed, J., Lam,S., Nora, A.A. and Noor,M.J.M.M. (2007): A simulation study of the removal efficiency of granular activated carbon on cadmium and lead. Desalination., 206: 9-16.

3. Ucer, A.,Uyanik, A., and Aygun, S.F. (2006): Adsorption of Cu (II), Cd (II), Zn (II), Mn (II) and Fe (III) ions by tannic acid immobilized activated carbon. Separ. Purify. Technol., 47: 113-118.

4. Ibrahim,K., Mehmet,U., Hamdi, K., and Ali, C. (2008): Adsorption of Cd (II) ions from aqueous solutions using activated carbon prepared from olive stone by $\mathrm{ZnCl}_{2}$ activation. Bioresource technol., 99: 429-501.

5. Chaouch, N., Ouahrani, M.R., Chaouch, S. and Gherraf, N. (2013): Adsorption of cadmium (II) from aqueous solutions by activated carbon produced from Algerian dates stones of Phoenix dactylifera.L by $\mathrm{H}_{3} \mathrm{PO}_{4}$ activation. Desali. Water. Treat. , 51: 2087-2092.

6. Amuda, O.S., Giwa, A.A., and Bello, I.A. (2007): Removal of heavy metal from industrial wastewater using modified activated coconut shell carbon. Biochem. Engine. J., 36: 174-181.

7. Faur, C.B. and Kadirvelu, K. P. (2002): Removal of metal ions from aqueous solution by adsorption onto activated carbon cloth: adsorption competition with organic matter. Carbon., 40: 2387-2392.

8. Vivek, N. and Mahesh, G. (2009): Use of adsorption using granular activated carbon (G.A.C) for the enhance of removal of chromium from synthetic wastewater by electrocoagulation. Journal. Haza. Mater., 161: 575-580.

9. Ayhan, D. (2008): Heavy metal adsorption onto agro based waste material. Journal. Haza. Mater., 157: 220-229. 
10. Tonni, A.K. (2006): Chemical treatment technique for wastewater laden with heavy metals. Chem. Engine. J., $118: 83-98$.

11. Puziy, A.M., Poddubnaya, O.I., Zaitsev, N.V. and Konoptiska, O.P. (2004): Modeling of heavy metal ion binding by phosphoric acic activated carbon. Applied. Surf. Sci., 221: 421-429.

12. Mac Donald, J.A.F. and Quinn, D.F. (1996): Adsorbents for methane storage made by phosphoric acid activation of peach pits. Carbon.,34: 1103-1108.

13. Abdessalem, O. and Mourad, B. (2013): Adsorption characteristics of silver ions onto activated carbon prepared from almond shell. Desali. Water. Treat. ,51: 2317-2326

14. Hanzlík1, P., Jehlička1, J., Weishauptová, Z. and Šebek, O. (2004): Adsorption of copper, cadmium and silver from aqueous solutions onto natural carbonaceous materials. Plant Soil Environ., 50 (6): 257-264. 